УДК 331

DOI: 10.17277/voprosy.2016.04.pp.194-197

\title{
BUSINESS-IDEAS CONTEST AS A TOOL FOR RAISING THE QUALITY OF HIGHER EDUCATION AND THE QUALITY OF LIFE
}

\author{
E. S. Mishchenko, M. S. Lukianenko, M. A. Istomin \\ Tambov State Technical University, Tambov, Russia \\ Reviewed by Doctor of Pedagogical Sciences, \\ Professor E. A. Rakitina
}

Keywords: business-ideas contest; contest of marketing research; quality of education; quality of life.

\begin{abstract}
The quality of life is defined. The core and structure of the business-ideas contest is described. It is proved that the contests complement the standard educational program and enhance its effect, and as a result - influence positively on the quality of life.
\end{abstract}

Nowadays we face difficult political, economic and social situation. International conflicts, wars, sanctions, embargo result in the tremendous drop of quality of life in many developed and developing countries. Governments of these countries need to solve the dilemma - to strengthen their positions in the international arena and to maintain the appropriate quality of life of their citizens at the same time.

In accordance with the Oxford Dictionary the quality of life is defined as "the standard of health, comfort, and happiness experienced by an individual or group" [1]. The Collins Dictionary defines the quality of life is "the general well-being of a person or society, defined in terms of health and happiness, rather than wealth" [2]. In the Business Dictionary the quality of life is defined as follows: "Daily living enhanced by wholesome food and clean air and water, enjoyment of unfettered open spaces and bodies of water, conservation of wildlife and natural resources, security from crime, and protection from radiation and toxic substances. It may also be used as a measure of the energy and power a person is endowed with that enable him or her to enjoy life and prevail over life's challenges irrespective of the handicaps he or she may have" [3]. Thus, the quality of life is a complex category that depends on many factors. For example, the Organisation for Economic Co-operation and Development (OECD) Better Life Index is determined using the following factors: housing, income, jobs, community, education, environment, civic

Мищенко Елена Сергеевна - доктор экономических наук, профессор, проректор по международной деятельности, e-mail: int@tstu.ru; Лукьяненко Маргарита Сергеевна аспирант кафедры «Менеджмент»; Истомин Михаил Александрович - кандидат экономических наук, начальник управления инновационной деятельности, ТамбГТУ, г. Тамбов, Россия. 
engagement, health, life satisfaction, safety, and work-life balance [4]. The Eurostat uses quite different factors: material living conditions, productive or main activity, health, education, leisure and social interactions, economic and physical safety, governance and basic rights, natural and living environment, overall experience of life [5].

Therefore, we can see that education is one of the key factors influencing the quality of life. Consequently, there is a correlation between the quality of education and the quality of life: the higher the quality of education is, the higher is the quality of life and vice versa.

In $2014-2015$, we conducted the survey among the students of Tambov State Technical University (TSTU) and Kazan National Research Technological University (KNRTU) on the quality of education. The survey findings showed that more than two thirds of respondents evaluated the quality of education in the universities as high and rather high compared to only $2 \%$ of unsatisfied respondents. The rest gave the medium score. At the same time about $15 \%$ of students noted that the amount of practical skills is insufficient to meet the requirements of the labor market.

The results of the survey proved that students need more practice and interaction with the representatives of the real economy sector. That is why in 2014 the lecturers of the Department of Management of TSTU collaborated to organize an additional extracurricular event for students and prospective students of the Department. We organized the contest, which was called "On the Way to the Startup". The aim of the contest was to help its participants to develop the business-model for a certain business idea. The participants got consultations of the organizers several times a week. The preparation for the presentation session took about two months. About 30 students and prospective students with 15 projects took part in the contest. Three lecturers of the Department and two representatives of small businesses were invited to judge the contest, choose the best project, and give some tips to the participants in terms of starting up the business. The participants presented such projects as a gym, a remote control models shop, a cafe for kids, and others. We obtained a very positive feedback from both experts and participants. All the experts agreed that the projects were made thoroughly and thoughtfully, and had real chance to be implemented. The students noted that the skills and knowledge obtained during the developing of their projects would be very useful for them to start up their own business or work in an organization.

In 2015, we decided to change the regulation of the contest: every student of TSTU could participate in the contest, not only students of the Department of Management. Prospective students of Tambov high schools were also invited to participate. The duration of the contest was expanded to three months. The contest itself was divided into three parts: the selection of participants, the semi-final, and the final. Participation was possible in groups up to three people or individually. More than 50 participants with almost 20 projects sent us requests, and only 25 participants with 13 projects managed to get to the final: an organic food shop, a soft cheese manufacturer, an exotic food restaurant and others. Training sessions on rhetoric, business planning, time management, and team building were complemented by weekly consultations by the lecturers of the Department. The experts at the final were managers of commercial organizations, representatives of TSTU, and heads of noncommercial associations. At present, several participants are still developing their projects as 
they are planning to start up a business in the chosen sphere after graduating from the university.

In the academic year $2015-2016$, we made a decision to organize one more contest - the contest of marketing research "The Market Factor". Its aim was to let students and prospective students work for an organization and do marketing research for it. The structure of the contest was practically the same: selecting participants, semi-final, final and training sessions with companies' representatives. First, participants prepared the market research of fast moving consumer goods: shampoo, tea, coffee, napkins and so on. It the semi-final there were 27 students and prospective students who presented the results of their research to the representatives of three companies: joint-stock company "Tambovnefteprodukt" ("Rosneft"), public joint-stock company "Tambovskiy Hlebokombinat", and limited liability company "AgroSoyuz". Each company gave the participants special tasks, and the students in turn had to complete them. Participants dealt with the companies very close. In the final, they presented the results. The experts were the same as in the semi-final. They all confirmed that students managed to complete all the tasks to a very high standard. Moreover, some participants got a job offer.

Several participants of "The Market Factor" also took part in "On the Way to the Startup - 2016". About 50 students, prospective students, and alumni participated in the third annual contest of business-ideas with 20 projects. The highlight of this contest was the prevalence of practice-oriented projects. Several alumni of TSTU requested to participate in the contest, because they needed some additional knowledge for starting up their businesses. The half of projects are under implementation, which means that the participants have already started up a business or have been preparing to do it in the nearest future. They participated in the contest to obtain knowledge and skills, which they lack.

Participating in such contests gives students an opportunity to make useful contacts with representatives of commercial and noncommercial organizations, get necessary knowledge and skills, and develop the necessary competences. These contests complement the standard educational program and enhance its effect, and as a result, they have a positive influence on the quality of life.

\section{References}

1. The Oxford Dictionaries, available at: https://en.oxforddictionaries.com/ definition/quality_of_life (accessed May 6, 2016).

2. The Collins Dictionary, available at: http://www.collinsdictionary.com/ dictionary/english/quality-of-life (accessed May 6, 2016).

3. The Business Dictionary, available at: http://www.businessdictionary.com/ definition/quality-of-life.html (accessed May 6, 2016).

4. OECD Better Life Index, available at: http://www.oecdbetterlifeindex.org/ countries/russian-federation/ (accessed 29.04.2016)

5. Eurostat, available at: http://ec.europa.eu/eurostat/statistics-explained/index.php/ Quality_of_life_indicators (accessed May 6, 2016).

6. Lukianenko M.S., Mishchenko E.S. All Round Questionnaire (ARQ) as the Tool for Raising Quality of Teaching, Proceedings of 2015 International Conference on Interactive Collaborative Learning (ICL), 20-24 September 2015, Florence, Italy, pp. 30-33. 
7. Mishchenko E.S., Lukianenko M.S. [Interconnection and interdependence of the categories "quality of the university teacher's labour" and "employee motivation], Vestnik federalnogo gosudarstvennogo obrazovatelnogo uchrezhdeniya vysshego professionalnogo obrazovaniya Moskovskiy gosudarstvenniy agroinshenerniy universitet im. V.P.Goryachkina [Bulletin of the Federal State Institution of Higher Professional Education Moscow State Agroengineering University named after V.P. Goryachkin], 2013, no. 4, pp. 123-125. (In Russ.)

\section{Список литературы}

1. The Oxford Dictionaries [Электронный pecypc]. - Режим доступа : https://en.oxforddictionaries.com/definition/quality_of_life (дата обращения: 6.05.2016).

2. The Collins Dictionary [Электронный pecypc]. - Режим доступа : http://www.collinsdictionary.com/dictionary/english/quality-of-life (дата обращения: 6.05.2016).

3. The Business Dictionary [Электронный pecypc]. - Режим доступа : http://www.businessdictionary.com/definition/quality-of-life.html (дата обращения: 6.05.2016).

4. OECD Better Life Index [Электронный pecypc]. - Режим доступа : http://www.oecdbetterlifeindex.org/countries/russian-federation/ (дата обращения: 29.04.2016).

5. Eurostat [Электронный pecypc]. - Режим доступа : http://ec.europa.eu/eurostat/ statistics-explained/index.php/Quality_of_life_indicators (дата обращения: 29.04.2016).

6. Lukianenko, M. S. All Round Questionnaire (ARQ) as the Tool for Raising Quality of Teaching / M. S. Lukianenko, E. S. Mishchenko // Proceedings of 2015 International Conference on Interactive Collaborative Learning (ICL), 20 - 24 September 2015, Florence, Italy. - Florence, Italy, 2015. - P. 30 - 33.

7. Мищенко, Е. С. Взаимосвязь и взаимозависимость категорий «качество труда преподавателя вуза» и «мотивация персонала» / Е. С. Мищенко, М. С. Лукьяненко // Вестник Федерального государственного образовательного учреждения высшего профессионального образования Московский государственный агроинженерный университет им. В. П. Горячкина. - 2013. - № 4. - С. 123 - 125.

\section{Конкурс предпринимательских идей как инструмент повышения качества высшего образования и качества жизни}

\section{Е. С. Мищенко, М. С. Лукьяненко, М. А. Истомин}

ФГБОУ ВО «Тамбовский государственный технический университет», г. Тамбов, Россия

Ключевые слова: качество образования; качество жизни; конкурс предпринимательских идей; конкурс маркетинговых исследований.

Аннотация: Определено качество жизни. Даны описания сущности и структуры конкурса предпринимательских идей. Приведено подтверждение тезису о том, что проводимые конкурсы положительным образом дополняют стандартную образовательную программу и, как следствие, положительно влияют на качество образования студентовучастников и качество их жизни.

(C) Е. С. Мищенко, М. С. Лукьяненко, М. А. Истомин, 2016

УНИВЕРСИТЕТ им. В.И. ВЕРНАДСКОГО. №4(62). 2016. 